\title{
JAARVERSLAG VAN DE CONSERVATOREN OVER 2015
}

\section{Aanwinsten van het Rijksmuseum}

\section{Japanse schilderingen}

- Seisui, Groene pijnbomen op het witte strand, rolschildering, I914, I98,3 X $83,8 \mathrm{~cm}$, aankoop Hotei Japanese prints, Leiden (AK-RAK-20I5-I)

- Shibata Zeshin, Lotuswortel met een muis, rolschildering, I8I7I89I, II 2 X 30,5 cm, schenking (samen met de andere onderstaande schilderingen) Jan Piet Filedt Kok, Amsterdam (AK-RAK-2015-2-I)

- Mori Ippô, Beer en krab bij een rots, rolschildering, I808-I87I, 57,8 X $80,5 \mathrm{~cm}$ (AK-RAK-2015-2-2)

- Tani Buncho, Setsubun festival: Shoki gooit bonen naar een duivel, rolschildering, I773-I842, 34 X 58,5 cm (AK-RAK-2015-2-3)

- Matsumura Goshun, Jongen op weg naar het rijstveld, rolschildering, I762-I8II, 4I, 8 x 54,9 cm (AK-RAK-20I5-2-4)

- Kôno Bairei, Tijger, rolschildering, I866, I27 x 28,7 cm (AK-RAK-2015-2-5)

- Nakajima Kahô, Tsurumeso bij het Gion festival, rolschildering, 1926, 26,4 x $50 \mathrm{~cm}$ (AK-RAK-2015-2-6)

- Takeuchi Seihô, Muis op de hamer van Daikoku, rolschildering, I874I942, 30 x 44,3 cm (AK-RAK-2015-2-7)

- Konoshima Ôkoku, Winterkraaien na de sneeuwval, rolschildering, I9I4, I33,5 X 30,6 cm (AK-RAK-2015-2-8)

- Rai San'yô, Kalebas met 57 zegels, rolschildering, I790-I832, 207 X 32,8 cm (AK-RAK-2015-2-9)

- Suzuki Shônen, Slak, rolschildering, I859-I9I8, IOo X 50,2 cm (AK-RAK2015-2-IO)

- Matsumura Keibun, Album met achttien tekeningen, I789-I843, 24,5 X 3I cm (AK-RAK-20I5-2-II)

- Shiokawa Burin, Album, I926, 29,I X 29,I cm (AK-RAK-2015-2-I2)

\section{Chinese keramiek}

- Een groep van zes neolithische voorwerpen, aardewerk, China, circa 2000 v.Chr., sinds 196I in bruikleen in het museum, aangekocht in 2015:

- Schenkkan, h. 20,3 cm (AK-RAK-2015-3-I)

- Schenkkan met een oor, h. 15,5 cm (AK-RAK-2015-3-2)

- Kom, h. 20 cm (AK-RAK-20I5-3-3)

- Vaas, h. 36,5 cm (AK-RAK-2015-3-4)

- Kom, h. 8,5 cm (AK-RAK-2015-3-5)

- Vaas, h. 32,5 cm (AK-RAK-20I5-3-6)

\section{Onderzoek}

- Dansende Shiva

In 2015 werd het onderzoek naar de Shiva Nataraja (AK-MAK-I87) voort-

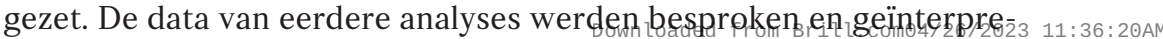


teerd en in oktober 2015 werden via de non-destructieve XRF-methode metingen verricht om de legering, vooral van de handen, vast te stellen. Het onderzoek werd uitgevoerd samen met het restauratieatelier van het Rijksmuseum (metaal) en Prof. Gareth Davis, Head of Geology and Geochemistry Research Cluster, Faculty of Earth and Life Sciences, Vrije Universiteit, Amsterdam. Het onderzoek zal in 2016 worden vervolgd.

\section{Tentoonstellingen}

Aan de volgende tentoonstellingen werden voorwerpen in bruikleen gegeven:

- 'The splendor of Korean Art'

Leeum, Samsung Museum of Art, Seoul, 2 juli - I3 september 2015

Soetradoos, lakwerk, Korea, $3^{\mathrm{e}}-\mathrm{I} 4^{\mathrm{e}}$ eeuw (AK-MAK-I78)

- 'Koffie, thee en tabak'

Het Noordbrabants Museum, 's-Hertogenbosch, 6 juni - 3I september 2015 Koffiekan in onderglazuur blauw met een voorstelling van 'de Parasoldames' van Cornelis Pronk, porselein, China, ca. I740 (AK-RBK-I96I-89)

- 'Azië > Amsterdam'

Rijksmuseum, Amsterdam, I6 oktober 2015 - I6 januari 2016

dekselpot, porselein, China, I620-I630 (AK-MAK-563)

kendi, porselein, China, I6oo (AK-MAK-ІзІо)

Op deze tentoonstelling was daarnaast een grote groep Aziatische voorwerpen uit de Rijksmuseumcollectie te zien

\section{Bezetting van de afdeling}

Op de afdeling Aziatische kunst werkten in het jaar 2015 vier conservatoren: Anna Ślączka voor Zuid-Azië, William Southworth voor ZuidoostAzië, Menno Fitski voor Oost-Azië en Jan van Campen voor Aziatische exportkunst. De post van conservator China was helaas nog niet vervuld, maar hieraan werd gedurende het jaar hard gewerkt. De afdeling werd versterkt met Denise Campbell, die eerder in het Groninger Museum had gewerkt. Zij werd in september voor een jaar aangesteld als projectmedewerker om te werken aan de beschrijvingen van de Aziatische keramiek in de computerinventaris van het Rijksmuseum.

\section{Publicaties}

\section{- Jan van Campen}

Redactie (met Karina H. Corrigan, Femke Diercks, en Janet C. Blyberg), essay 'The hybrid world of Batavia', en verschillende hoofdstukken in: Asia in Amsterdam, the culture of luxury in the Golden Age, Salem/Amsterdam, 20I5. [tent.cat. Peabody Essex Museum Salem en Rijksmuseum.]

(Met Mariette Haveman), 'Exotische luxe; een sprookje van Nederlands fabricaat', Kunstschrift Azië in Amsterdam 59/5 (2015), pp. 2-II.

(Met Tristan Mostert) Zijden Draad; China en Nederland sinds I6oo/Silk Thread; China and the Netherlands from I6oo, Amsterdam/Nijmegen, 2015 . 
'Moeder met kind; een "verboden" beeld uit $\mathrm{I}^{\mathrm{e}}$-eeuws China', Vind; geschiedenis, archeologie, kunst en antiek 20 (2015), pp. 96-97.

'Asia in Amsterdam exotic luxury in the Golden Age', IIAS The Newsletter 72 (Autumn 20I5), p. 5I.

(Met Menno Fitski) 'Bekoorlijke educatie: een interview met Jan-Maarten Boll', Aziatische Kunst 45/I (2015), pp. I4-I7.

'Azië in Amsterdam, luxe in de Gouden Eeuw', Aziatische Kunst 45/3 (2015), pp. 3-IO.

Aziatische exportkunst / Asian export art', in: Aziatische Kunst [in het Rijksmuseum] / Asian Art [in the Rijksmuseum], Amsterdam, 2014, pp. 248-30I. [versch. 20I5]

\section{- Menno Fitski}

(Met Jan van Campen) 'Bekoorlijke educatie: Een interview met JanMaarten Boll', Aziatische Kunst 45/I (2015), pp. I4-I7.

'Wisselen in het Aziatisch Paviljoen: Kunst voor iedere gelegenheid', Aziatische Kunst 45/2 (2015), pp. 44-45.

'Wisselen in het Aziatisch Paviljoen: Porselein in het interieur', Aziatische Kunst 45/3 (2015), pp. IO-I2.

'Japanse kunst / Japanese art', in Aziatische Kunst [in het Rijksmuseum] / Asian Art [in the Rijksmuseum], Amsterdam, 2014, pp. I92-247. [versch. 2015]

\section{- Anna Ślączka}

'Dancing Siva images from Bengal', in: Mokammal H. Bhuiyan (red.), Studies in South Asian Heritage: Essays in Memory of M. Harunur Rashid, Dhaka, 2015, pp. I25-I55.

'Moderne Indiase kunst in het Rijksmuseum: Subodh Gupta', Aziatische Kunst 45/I (20I5), pp. 45-48.

'Shenchen er guili: Amusitedan guojia bowuguan de yindu yishu shoucang [Profound and surpassingly beautiful: the collection of Indian Art in the Rijksmuseum, Amsterdam]', Diancang gumeishu [Art \& Collection] 270 (2015), pp. I22-I29. Ook verschenen in: Diancang dutianxia [Artco China].

'Recent Asian Acquisitions: Somaskanda', The Rijksmuseum Bulletin 63/4 (2015), pp. 408-409.

'Zuid-Indiase kunst / South Asian art', in Aziatische Kunst [in het Rijksmuseum] / Asian Art [in the Rijksmuseum], Amsterdam, 20I4, pp. 277I. [versch. 20I5]

- William Southworth

'Conceptual restoration 2: A body in Cambodia', Aziatische Kunst 45/2 (2015), pp. I2-I8.

'Zuidoost-Aziatische Kunst / Southeast Asian Art', in: Aziatische Kunst [in het Rijksmuseum] / Asian Art [in the Rijksmuseum], Amsterdam, 20I4, pp. 72-II9. [versch. 2015]

\section{Lezingen}

- Jan van Campen Asia in Amsterdam, the culture of luxury in the Golden Age, conferentie 'Sugar and spice and all things nice', Universiteit van Amsterdam, I3 maart 
(Met Femke Diercks) Azië in Amsterdam, luxe in de Gouden Eeuw, voor de patronen van het Rijksmuseum, i3 oktober

Azië in Amsterdam, luxe in de Gouden Eeuw, Dag van de Geschiedenis, Haarlem, I8 oktober

Azië in Amsterdam, luxe in de Gouden Eeuw, voor de VVAK, Rijksmuseum, 2I oktober

Asia in Amsterdam, the culture of luxury in the Golden Age, voor de Oriental Ceramic Society, Rijksmuseum, 23 oktober

Azië in Amsterdam, luxe in de Gouden Eeuw, 'Avondje Azië', Rijksmuseum, 23 oktober

(Met Femke Diercks) Azië in Amsterdam, luxe in de Gouden Eeuw, Rijkslezing, Rijksmuseum, I november

(Met Femke Diercks) Azië in Amsterdam, luxe in de Gouden Eeuw, vriendenavond van het Rijksmuseum, 4 november

Asia in Amsterdam, the culture of luxury in the Golden Age, Inleiding op het gelijknamige symposium, Rijksmuseum, 9 november

Illustrious Monument / Unhappy Ruines; the Leeuwarden lacquer room in the Rijksmuseum, Rijksmuseum, ter gelegenheid van het verschijnen van het boek Zijden Draad, 27 november

De Leeuwarder lakkamer in het Rijksmuseum, presentatie en paneldiscussie in Spui 25 ter gelegenheid van het verschijnen van het boek Zijden Draad, , o december

Azië in Amsterdam, luxe in de Gouden Eeuw, Openbare Bibliotheek Amsterdam, I5 december

- Menno Fitski

Japans porselein en lakwerk, Vereniging Oudheidkamer voor Tiel en Omstreken, Tiel, Io februari

'Sekai wo maryō shita Aritayaki' ('Arita porselein dat de wereld fascineerde'), lezing symposium Aritayaki no dentō to mirai e tsuzuku sōzōsei (Arita porselein: traditie en vooruitkijkende creativiteit), Kyushu National Museum, Fukuoka, 8 maart

Japans keramiek voor de theeceremonie, college Universiteit Leiden, I5 april

Japanese porcelain, college Sotheby's Institute of Art, Londen, 29 april

The practice of curating, WeberWorldCafé: Museum, Power and Identity, Museen Dahlem, Berlijn, II juni

The collection of Korean art at the Rijksmuseum Amsterdam: small but exquisite, Korean Collections in Europe: 2015 Overseas Korean Cultural Heritage Foundation Forum, Seoul, 27 oktober

Japanese lacquer imports: the case of the Amsterdam chest, Symposium Asia in Amsterdam, Rijksmuseum, 9 november

Japanse kunst in het Rijksmuseum, Rijkslezing, Rijksmuseum, 20 november

- Anna Ślączka

The development of the ratnanyāsa (placing of gems) ritual on the basis of textual sources, with special attention to the Devyāmata, I6th World Sanskrit Conference, Silpakorn University, Bangkok, Thailand, 28 June-2 July 2015

The iconography of the Tamil Deity Karuppannasamy, with special attention to metal images, I7th Symposium of the American Gouncil And $_{\text {11:36:20AM }}$ 
for Southern Asian Art (ACSAA), Royal Ontario Museum, Toronto, I5-I7 October 2015

What is Indian art?, Amsterdam University College, Amsterdam, I6 november 2015

Art for each day of the year: the Pavilion for Asian art at the Rijksmuseum, presentatie voor de Oriental Ceramics Society, Rijksmuseum, 23 oktober 2015

Nataraja: een blijvend mysterie', Vriendenavond Rijksmuseum, 4 november 2015

Rijkscollege Aziatische Kunst: India, Rijksmuseum, 4 december 2015

- William Southworth

The rise of Southeast Asian prehistory: Heine-Geldern's recognition of the Dong Son culture and of a regional bronze tradition, gehouden op de 8th European Association for Southeast Asian Studies Conference (georganiseerd door de Universiteit Wenen en de Oostenrijkse Academie van Wetenschappen), Wenen, I2 augustus

Zuidoost-Aziatische kunst, Rijkscollege, Rijksmuseum, 27 november

\section{Nevenactiviteiten}

- Jan van Campen

lid keuringscommissie Aziatische exportkunst TEFAF

lid keuringscommissie Aziatische kunst PAN

lid redactie Rijksmuseum Bulletin

lid redactie Aziatische Kunst

- Menno Fitski

lid bestuur Hulsewé-Wazniewski Stichting

lid bestuur Stichting Tikotin

lid bestuur Stichting für Elise

lid bestuur Stedenband Leiden-Oxford

lid redactie Aziatische Kunst

- Anna Ślączka

lid bestuur Vereniging Vrienden van Instituut Kern (VVIK), Universiteit Leiden

lid redactie Aziatische Kunst

- William Southworth

lid bestuur onderzoeksproject Corpus des Inscriptions du Campā van

het École française d'Extrême-Orient (EFEO), Parijs

lid redactie Aziatische Kunst 
$M O$

A $R$

R I

C E

E N

L T

A

N L

E A

$S R$
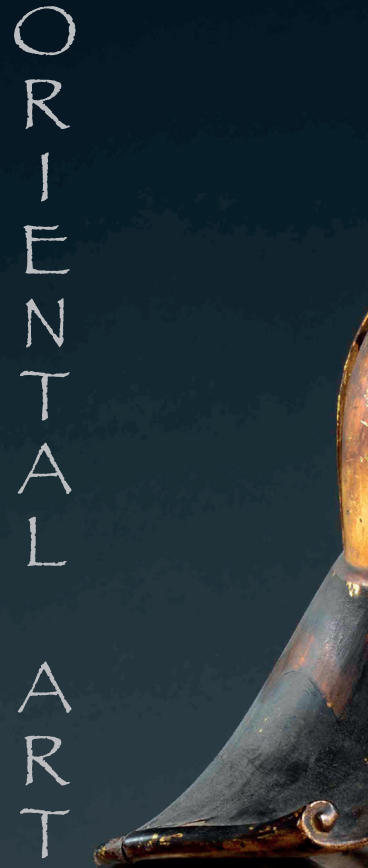


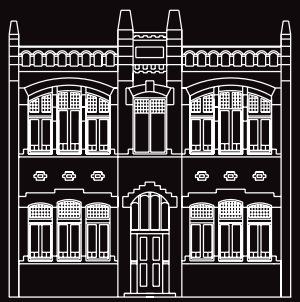

\section{ZeEuWs Veilinghuis} Z E E L A N D A U C T I O N E E R S

\section{AZIATICA VEILING MAART 2017}

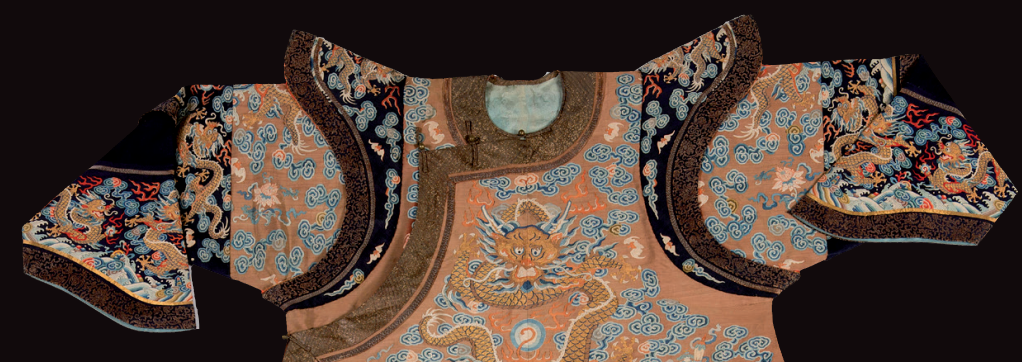

Zijden jas, China $19^{e}$ eeuw Hamerprijs $€ 55.000$,(20 september 2016)

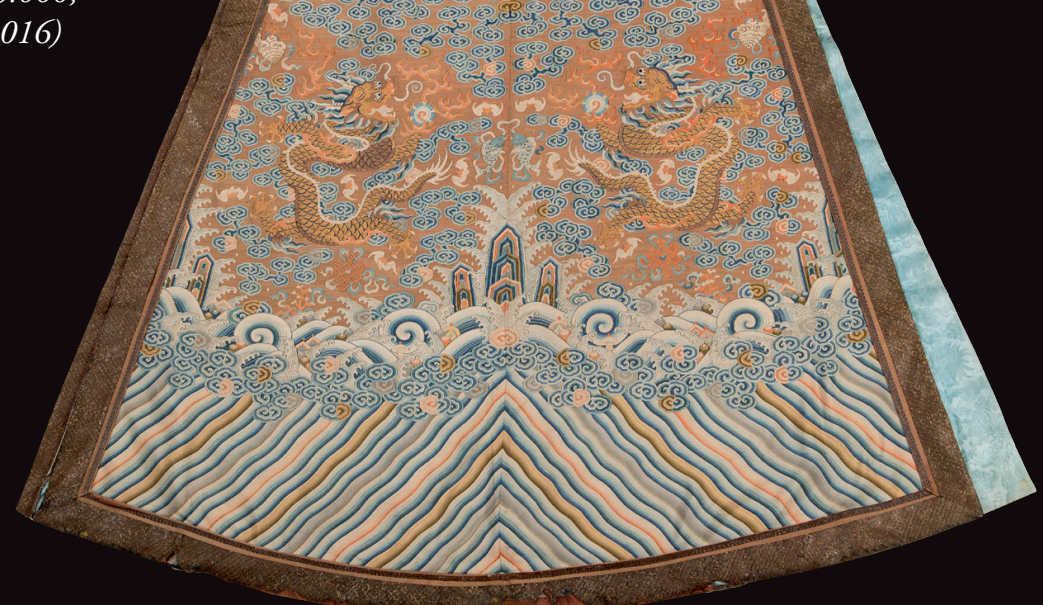

NIEUW INNAMEKANTOOR:

HERENGRACHT 566 AMSTERDAM

TEL. O2O - 2602233 (OP AFSPRAAK)

HOOFDKANTOOR: HERENGRACHT 74 433 I PX MIDDELBURG TEL. OI I 8 - 650680 WWW.ZEEUWSVEILINGHUIS.NL | INFO@ZEEUWSVEILINGHUIS.NL 


\section{AstamangaLA}

OUDE KUNST UIT TIBET, NEPAL EN INDIA

KEIZERSGRACHT 574 • 1017 EM AMSTERDAM (SPIEGELKWARTIER)

TEL: 020-6234402・E-MAIL: ASTA@XS4ALL.NL・WWW.ASTAMANGALA.COM

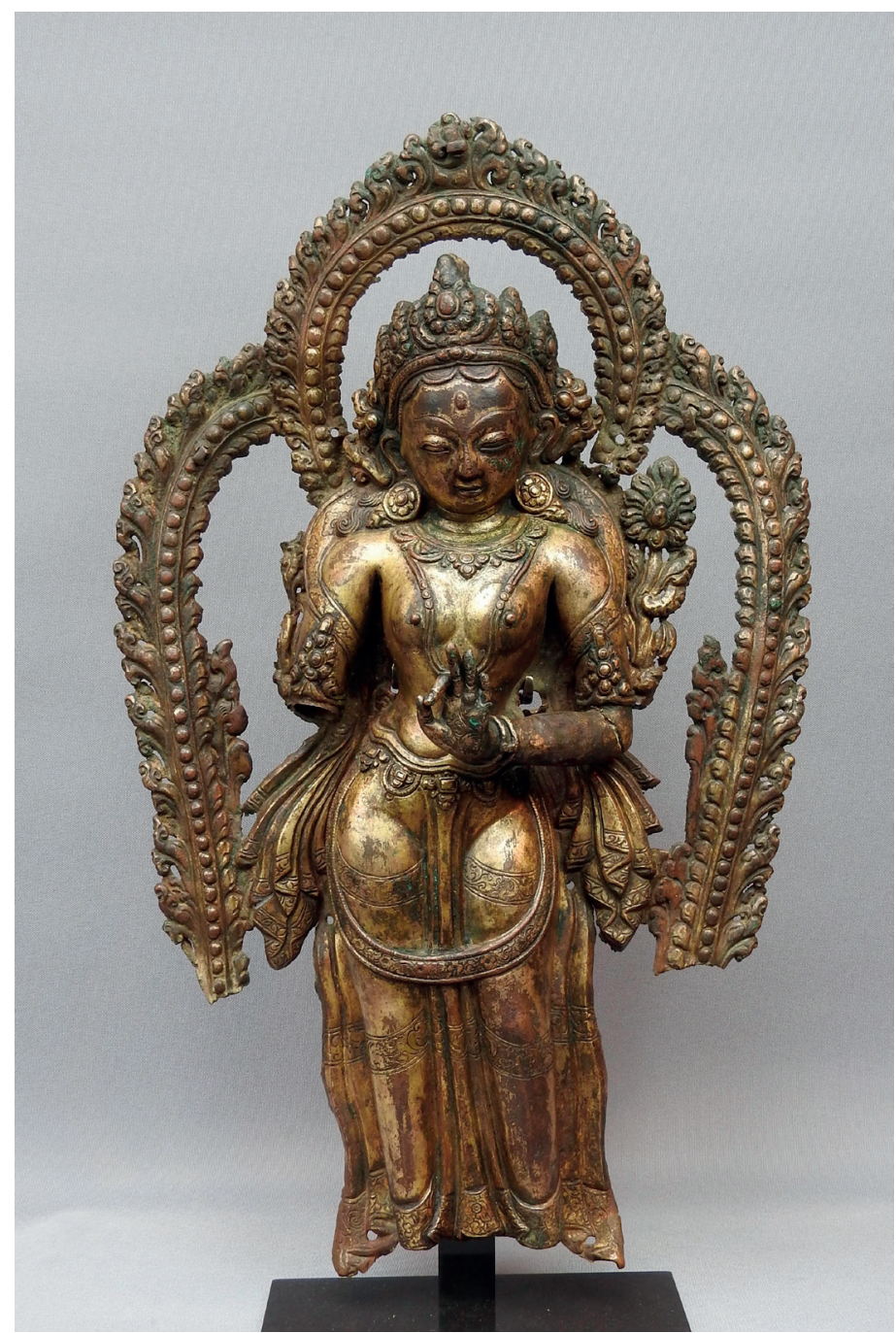

Staande Tara

vuurverguld koper repoussé

Nepal, 16de eeuw, hoog: $36 \mathrm{~cm}$. 


\section{GUUS RÖELL FINE ART}

Tel.: 0653211649 | e-mail: g.roell@xs4all.nl | website: www.guusroell.com Tongersestraat 2, $6211 \mathrm{LN}$ Maastricht
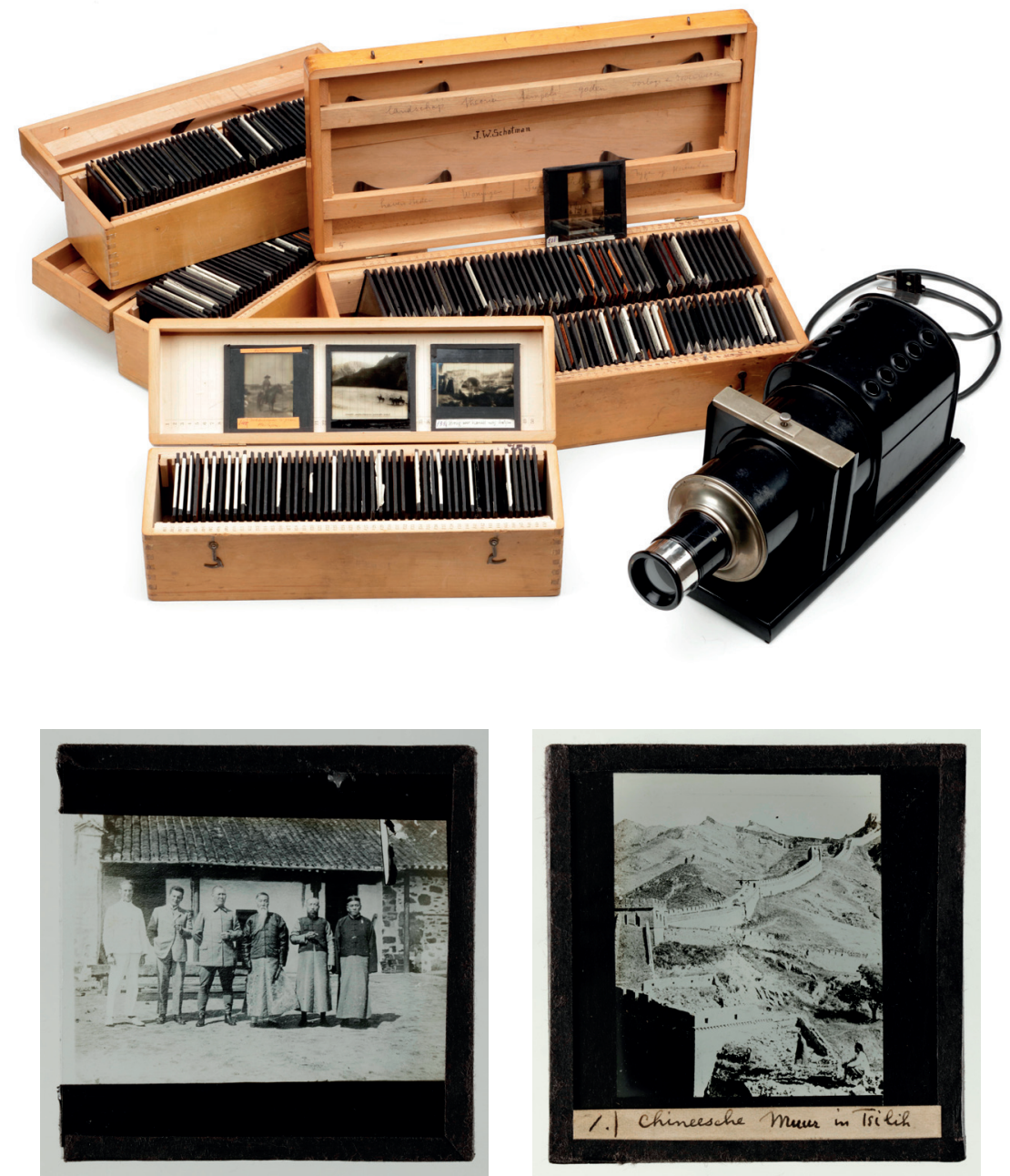

Een collectie van 256 toverlantaarn plaatjes van China tussen I92I en I927, gefotografeerd door Johan Wilhelm Schotman (I892-1976). 


\section{Frides Laméris}

\section{KUNST- EN ANTIEKHANDEL VOF}

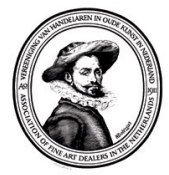

Nieuwe Spiegelstraat 55

IOI7 DD Amsterdam

Telefoon 020-6264066

info@frideslameris.nl

www.frideslameris.nl

glas - ceramiek

objets de collection

Een waterdruppelaar. Porselein, 'redspotted Qingbai'.

Yuan. I279-I386. Jing de zhen, China. Lengte II,8 cm.

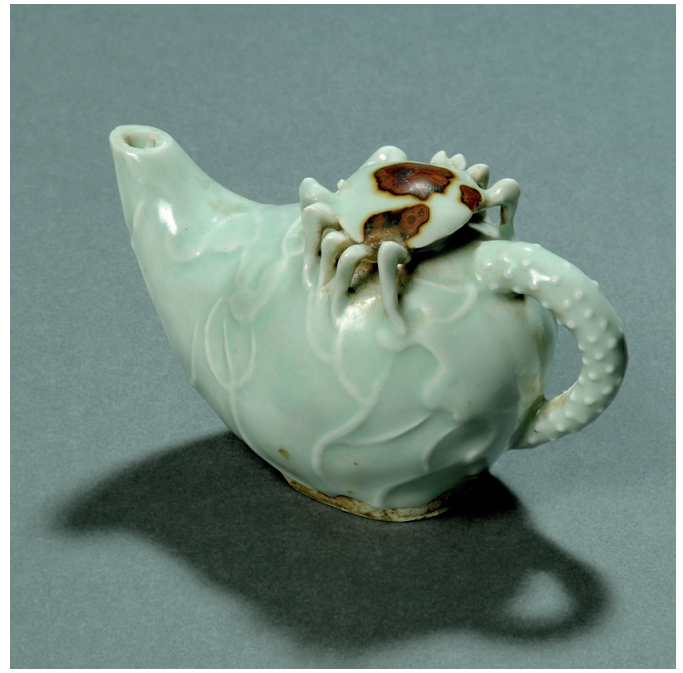

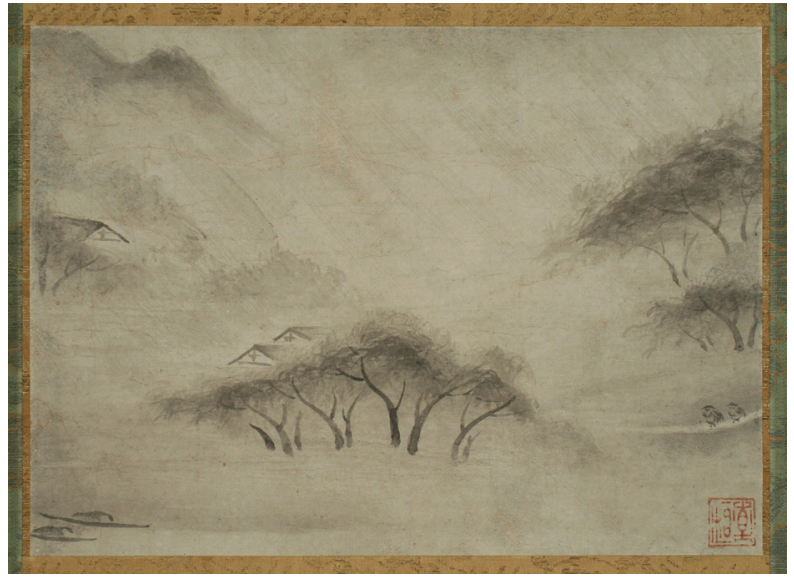

Soami (1472-1525)

(toegeschreven)

Regenlandschap in de stijl van Mu Qi Fachang (I2IO?-I269)

Zegel: Shinsô

Rolschildering op papier, $25.5 \times 35.7$, in brokaat montering, II $549.5 \mathrm{~cm}$

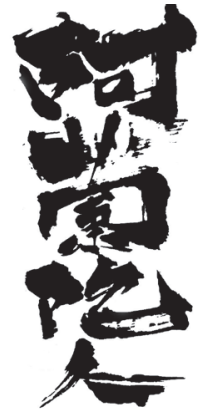

ORANDA JIN

Japanese paintings \& painters' pottery

Kalverstraat 28

$5223 \mathrm{AD}$ 's-Hertogenbosch tel: +31 (0)73-621 8951 e-mail: orandajin@home.nl www.orandajin.com (nieuwe update eerste week van de maand) 
www.patergratiaorientalart.com

Pater Gratia Oriental Art?

Specialized in fine Chinese and Japanese

17 th and 18th century Export Porcellain
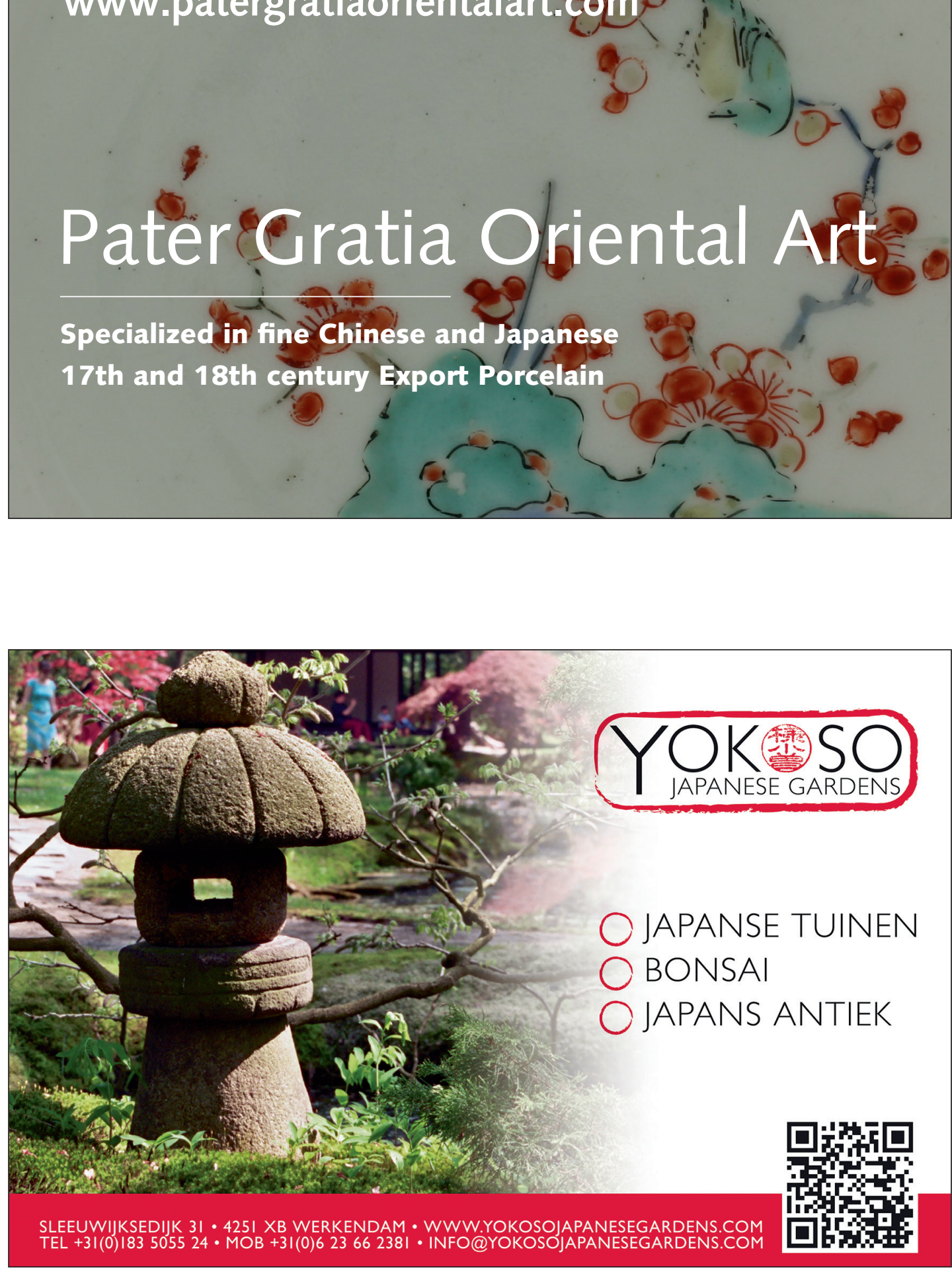